\title{
ANALISIS KESULITAN MAHASISWA DALAM MENUMBUHKAN KEMAMPUAN BERPIKIR KRITIS MELALUI PEMECAHAN MASALAH
}

\author{
Indri Anugraheni \\ PGSD, Universitas Kristen Satya Wacana \\ Indri.anugraheni@uksw.edu
}

\begin{abstract}
The purpose of this study is to describe the difficulties experienced by students in developing critical thinking skills in mathematics through problem solving learning. This research needs to be done because of the low ability of students critical thinking in solving mathematical problems. This research is descriptive research. The subjects of this study were 64 students of PGSD. Data obtained by distributing instruments in the form of questionnaires. The results showed that $64.06 \%$ of students had difficulty in solving problems; $53.13 \%$ of students had difficulty finding alternative solutions to the problems given. The ability of students to think critically appears from $67.19 \%$ of students are able to understand mathematical problems, $85.94 \%$ of students are able to check and draw conclusions from the problems given.
\end{abstract}

Keywords: Difficulty Analysis, Critical Thinking Mathematics

\begin{abstract}
Abstrak
Tujuan penelitian ini adalah mendeskripsikan kesulitan-kesulitan yang dialami mahasiswa dalam menumbuhkan kemampuan berpikir kritis matematika melalui pembelajaran pemecahan masalah. Penelitian ini perlu dilakukan karena rendahnya kemampuan berpikir kritis mahasiswa dalam pemecahan masalah matematika . Penelitian ini merupakan penelitian deskriptif. Subjek penelitian ini adalah mahasiswa PGSD yang berjumlah 64 mahasiswa. Data diperoleh dengan cara menyebarkan instrument yang berupa kuesioner. Hasil penelitian menunjukkan bahwa 64,06\% mahasiswa kesulitan dalam menyelesaikan masalah; 53,13\% mahasiswa kesulitan mencari alternatif penyelesaian dari permasalahan yang diberikan. Kemampuan berpikir kritis mahasiswa tampak dari $67,19 \%$ mahasiswa mampu memahami permasalahan matematika, 85,94\% mahasiswa mampu memeriksa dan menarik kesimpulan dari permasalahan yang diberikan.
\end{abstract}

Kata kunci: analisis kesulitan, berpikir kritis matematika

Berpikir kritis adalah individu yang rasional, mampu berpikir reflektif, dan mampu mengambil keputusan berdasarkan pertimbangan yang matang (Sani, 2019). Berpikir reflektif merupakan proses berpikir yang melibatkan kemampuan berpikir kritis dan kreatif dalam menyelesaikan permasalahan. Wijaya (Ibrahim, 2007) berpikir kritis merupakan kegiatan menganalisis gagasan kearah yang spesifik, membedakan suatu hal secara tajam, memilih, mengidentifikasi.

Gerhard menjelaskan berpikir kritis sebagai proses kompleks yang melibatkan penerimaan, penguasaan data, analisis data, evaluasi serta membuat seleksi atau membuat keputusan berdasarkan hasil evaluasi (Maulana, 2017). Brillian Rosy \& Triesninda Pahlevi (2015) berpikir kritis yang dilakukan adalah proses terorganisasi yang melibatkan aktivitas mental mencakup kemampuan seseorang dalam merumuskan masalah, memberikan argumen, menyusun laporan, melakukan dedukasi, induksi, memutuskan kemudian melaksanakan, dan berinteraksi dengan yang orang lain untuk memecahkan masalah. Berpikir kritis mambuat seseorang mampu untuk mengatur, menyesuaikan, mengubah atau memperbaiki pikirannya, sehingga dapat mengambil keputusan untuk 
bertindak lebih cepat (Maulana, 2017). Sebelum mengambil keputusan, seseorang mengalami proses rasional. Proses rasional dalam berpikir kritis bertujuan untuk membuat keputusan apakah meyakini atau melakukan sesuatu (Haryani, 2011). Sejaln pendapat Wiliawanto, dkk (2019) menyebutkan berpikir kritis merupakan bagian terpenting dari tujuan sebuah pembelajaran. Berdasarkan beberapa penjelasan diatas maka berpikir kritis merupakan proses dinamis yang memungkinkan mahasiswa/siswa mampu mendeteksi perbedaan informasi, mengumpulkan data, menganalisis data yang diperoleh, mengevaluasi dan menyimpulkan informasi/data yang diperoleh.

Perubahan paradigma dalam kegiatan proses perkuliahan/pembelajaran yang awalnya berpusat pada guru (teacher centered) kini berkembang menjadi kegiatan pembelajaran yang berpusat pada siswa (learner center). Kegiatan perkuliahan/pembelajaran yang berpusat pada siswa/mahasiswa (learner centered). Diharapkan siswa/mahasiswa memiliki kemampuan dalam mengembangkan pengetahuan, keterampilan dan sikap. Salah satu model pembelajaran yang berpusat pada siswa adalah pembelajaran berbasis masalah atau dikenal dengan pemecahan masalah .

Garofalo dan Lester (1985) menjelaskan bahwa pemecahan masalah adalah proses yang mencakup visualisasi, sosiasi, abstraksi, pemahaman, manipulasi, bernalar, analisis, sintesis, dan generalisasi, yang masing-masing indikator harus diatur dan dikoordinasikan. Pemecahan masalah merupakan suatu rangkaian aktivitas pembelajaranyang menekankan pada proses penyelesaian masalah yang dihadapi secara ilmiah (Komariah, K; 2011). Polya (1973) menyatakan bahwa langkah-langkah pembelajaran pemecahan masalah yaitu: 1) memahami masalah, 2) menentukan rencana strategi yang tepat untuk menyelesaikan permasalahan, 3) menyelesaikan strategi penyelesaian masalah, 4) memerikasa dan menarik kesimpulan dari jawaban penyelesaian masalah tersebut. Pembelajaran pemecahan masalah sangat berpengaruh terhadap kemampuan berpikir kritis siswa (Ristiasari, dkk; 2012). Dapat kita simpulkan bahwa pemecahan masalah mampu menumbuhkan pemikiran kritis dan kreatif mahasiswa melalui kegiatan menganalisis argument, mempertimbangkan alternative penyelesaian, mengevaluasi, dan menyimpulkan permasalahan yang diberikan kepada mahasiswa.

Kegiatan menganalisis argument, mempertimbangkan alternative penyelesaian suatu permasalahan, mengevaluasi serta menarik kesimpulan harus muncul dalam kegiatan pembelajaran khususnya bagi mahasiswa. dalam kegiatan pembelajaran mampu mengubah pola pikir mahasiswa untuk menjadi kritis dan kreatif. Pembelajaran adalah proses interaksi yang terjalin antar peserta didik (mahasiswa), antara peserta didik (mahasiswa) dengan pendidik dan sumber belajar pada lingkungan belajar (UU permendikbud no 23, Tahun 2016). Kegiatan pembelajaran di perguruan tinggi tidak hanya mengembangkan dari aspek akademis (kognitif) saja tetapi juga mengembangkan keterampilan yang dimiliki mahasiswa khususnya keterampilan berpikir kritis mahasiswa.

Mata kuliah matematika merupakan mata kuliah yang tidak hanya melihat aspek kognitifnya saja tetapi juga aspek keterampilan mahasiswa. Tujuan mata kuliah strategi pemecahan masalah adalah 
Analisis Kemampuan Koneksi Matematis Siswa SMK Pada Materi Fungsi Kelas XI, Arpin Chronika Saida Manalu, Asri

mahasiswa mampu menerapkan pemikiran logis, kritis, sistematis dan inovatif dalam konteks pengembangan atau implementasi ilmu pengetahuan dan teknologi. Perkuliahan strategi pemecahan masalah mampu menumbuhkan pemikiran kritis dengan memberikan permasalahan-permasalahan matematika yang berkaitan dengan kehidupan sehari-hari kepada mahasiswa. Kemampuan berpikir kritis sangat dibutuhkan bagi mahasiswa khususnya mahasiswa PGSD agar ketika mereka nanti terjun ke dua kerja mampu mengatasi dan menyelesaiakan masalah-masalah yang dihadapi.

Kenyataan dilapangan mahasiswa masih kesulitan dalam menyelesaikan permasalahan yang berakaitan dengan berpikir kritis. Mahasiswa kurang memahami permasalahan kemampuan berpikir kritis terkait dengan indikator: kemampuan mahasiswa mendefinisikan permasalahan matematika yang diberikan, kemampuan mahasiswa memilih informasi yang relevan untuk menyelesaikan permasalahan, kemampuan mahasiswa untuk mengembangkan dan memilih hipotesisi yang relevan, serta kemampuan memutuskan kesimpulan dari permasalahan yang diberikan. Oleh karena itu, peneliti peneliti mencoba menerapkan pembelajaran pemecahan masalah untuk menumbuhkan kemampuan berpikir kritis. Setiap tahapan dalam pemecahan masalah memerlukan kemampuan berpikir kritis siswa (Haryani, 2011). Dalam kegiatan pembelajaran pemecahan masalah ditemukan banyak sekali kesulitan dalam menyelesaikan masalah. Oleh karena itu permasalahan dalam penelitian ini adalah mendeskripsikan kesulitan-kesulitan yang dialami mahasiswa dalam menumbuhkan kemampuan berpikir kritis pada pembelajaran matematika dengan menggunakan model pembelajaran pemecahan masalah.

\section{METODE}

Penelitian ini menggunakan metode deskriptif. Subjek penelitian ini adalah mahasiswa PGSD kangkatan $2017 \mathrm{C}$ dan 2017F yang berjumlah 64 mahasiswa. Teknik pengumpulan data dengan menggunakan kuesioner. Kuesioner dianalisis dengan cara mencari frekuensi dan presentase dari hasil kuesioner, kemudian hasil presentase kuesiner digunakan untuk mendeskripsikan kesulitan-kesulitan yang dialami mahasiswa dalam pembelajaran pemecahan masalah .

\section{HASIL DAN PEMBAHASAN}

Model pembelajaran pemecahan masalah merupakan pembelajaran yang menumbuhkan kemampuan berpikir kritis mahasiswa dalam menyelesaiakan permasalahan yang dihadapi baik secara individu maupun kelompok. Dosen mempunyai peran penting dalam memberikan masalah atau permasalahan kepada mahasiswa yang mampu merangsang mahasiswa untuk mampu berpikir kritis. Kemampuan berpikir kritis mahasiswa dapat berkembang melalui pembelajaran pemecahan masalah . Peneliti mengamati bahawa kemampuan berpikir kritis mahasiswa tampak dari kemampuan mahasiswa mengidentifikasi masalah, menganalisis masalah, memecahkan masalah, mampu berpikir logis serta mahasisiwa mampu membuat kesputusan atau kesimpulan dari permasalahan yang diberikan. Berpikir kritis ini sama dengan model pembelajaran pemecahan masalah dengan langkah-langkah Polya yaitu: memahami, merencanakan, menyelesaikan dan menarik kesimpulan dari permasalahan tersebut. Hal ini 
sejalan dengan Haryani (2011) langkah-langkah pemecahan masalah menurut Polya sangat diperlukan kemampuan berpikir kritis mulai dari tahap memahami masalah, tahap merencanakan pemecahan, tahap melaksanakan rencana, sampai dengan tahap memeriksa kembali pemecahan yang sudah dilaksankan. Watson \& Glaser (dalam Sani, 2019) menyebutkan empat keterampilan yang berkaitan dengan berpikir kritis, yakni: 1) kemampuan mendefinisikan permasalahan, 2) kemampuan memilih informasi yang relevan untuk menyelesaikan masalah, 3) kemampuan mengembangkan dan memilih hipotesis yang relevan, 4) kemampuan melegimitasi kesimpulan serta mengevaluasi inferensi.

\section{Tabel 1.}

Hasil analisis Kesulitan Mahasiswa dalam proses berpikir kritis Mahasiswa

\begin{tabular}{|l|c|c|c|}
\hline Indrikator & \multicolumn{2}{|c|}{ Presentase } & $\begin{array}{c}\Sigma \\
(\%)\end{array}$ \\
\cline { 2 - 4 } & Baik & Kurang & \\
\hline Kemampuan mendefinisikan permasalahan & 67,19 & 32,81 & 100 \\
\hline $\begin{array}{l}\text { Kemampuan memilih informasi yang relevan } \\
\text { untuk menyelesaikan masalah }\end{array}$ & 46,88 & 53,13 & 100 \\
\hline $\begin{array}{l}\text { Kemampuan mengembangkan dan memilih } \\
\text { hipotesis yang relevan }\end{array}$ & 35,94 & 64,06 & 100 \\
\hline $\begin{array}{l}\text { kemampuan melegimitasi kesimpulan dan } \\
\text { mengevaluasi inferensi. }\end{array}$ & 85,94 & 14,06 & 100 \\
\hline
\end{tabular}

Tabel 1 merupakan kemampuan berpikir kritis mahasiswa melalui pembelajaran pemecahan masalah. Hasil analisis menunjukan bahwa 67,19\% mampu mendefinisikan permasalahan matematika yang diberikan; 32,81\% belum mampu memahami permasalahan matematika yang diberikan. Kemampuan mahasiswa memilih informasi yang relevan untuk menyelesaikan masalah sebesar 46,88\%; 53,13\% mahasiswa mengalami kesulitan dalam memilih informasi yang relevan untuk menyelesikan permasalahan matematika. Hasil analisis 35,94\% mahasiswa memilih dan mengembangkan hipotesis yang relevan; 64,06\% mahasiswa masih kesulitan dalam memilih dan mengembangkan hipotesis yang relevan dengan permasalahan yang diberikan. Hasil analisis $85,95 \%$ mahasiswa melegitimasi (keputusan) kesimpulan dan mengevaluasi inferensi; 14,06\% mahasiswa kesulitan dalam mengambil keputusan dari kesimpulan sertamengevaluasi inferensi.

Kesulitan-kesulitan yang dialami mahasiswa dalam menumbuhkan kemampuan berpikir kritis adalah kemampuan memilih informasi yang relevan dengan permasalahan matematika. Hasil presentase 
Analisis Kemampuan Koneksi Matematis Siswa SMK Pada Materi Fungsi Kelas XI, Arpin Chronika Saida Manalu, Asri

menunjukkan 53,13 mahasiswa masih kesulitan dalam menentukan alternatif penyelesaian atau memilih informasi yang relevan dalam penyelesaikan masalah. Mahasiswa juga mengalami kesulitan dalam mengembangkan/menyelesaikan permasalahan matematika dan memilih hipotesis yang relevan dengan presentase sebesar 64,04. Mahasiswa tidak mengalami kesulitan dalam mendefinisikan permasalahan matematika dengan ditunjukan hasil presentase sebesar 67,19. Mahasiswa juga tidak mengalami kesulitan dalam mengambil keputusan dan mengevaluasi permasalahan yang diberikan, ditunjukan dari hasil presentasi sebesar 85,94 mahasiswa mampu mememeriksa dan menarik kesimpulan dari permasalahan yang diberikan.

Pembelajaran dengan pemecahan masalah mampu menumbuhkan berpikir kritis mahasiswa terutama pada kemampuan mendefinisikan atau memahami permasalahan yang diberikan, mahasiswa mampu menarik kesimpulan serta mengevaluasi dari permasalahan yang diberikan. Kemampuan menumbuhkan berpikir kritis tidak lepas dari kemampuan mahasiswa dalam memecahkan permasalahan. Mahasiswa mampu memahami permasalahan, menganalisis permasalahan yang diberikan, merencanakan permasalahan yang diberikan, mampu menarik kesimpulan dari permasalahan yang diberikan (Polya, 1973). Sejalan dengan Haryani (2011) bahwa langkah-langkah pembelajaran polya (pembelajaran pemecahan masalah) sangat diperlukan kemampuan berpikir kritis. Relevan dengan penelitian yang dilakukan Lubis (2017) bahwa pemecahan masalah mampu meningkatkan kemampuan berpikir kritis mahasiswa.

Hasil analisis menunjukkan bahwa 79,69\% mahasiswa setuju jika pembelajaran pemecahan masalah mampu menumbuhkan kreativitas mahasiswa. Kreativitas ini muncul ketika mahasiswa mampu menyelesaikan permasalahan matematika yang diberikan. Kemampuan mahasiswa dalam memikirkan ide-ide kreatif didalam menyelesaikan permasalahan matematika. Setiap permasalahan matematika, mahasiswa mampu menemukan menemukan lebih dari satu ide/solusi penyelesaian. langkah-langkah pembelajaran pemecahan masalah mampu menumbuhkan berpikir kreatif peseta didik melalui pembelajaran pemecahan masalah sejalan dengan pernyataan Palobo (2015).

\section{KESIMPULAN}

Berdasarkan hasil analisis kesulitan-kesulitan yang dihadapi mahasiswa dalam menumbuhkan kemampuan berpikir kritis adalah 1) mahasiswa kesulitan dalam menentukan alternatif dari permasalahan yang diberikan, 2) mahasiswa kesulitan dalam memilih dan menyelesaikan permasalahan matematika yang diberikan dosen, 3) permaslahan matematika sulit dipahami mahasiswa. Penyebab mahasiswa mengalami kesulitan dalam menumbuhkan berpikir kritis adalah sebagai berikut: 1) mahasiswa tidak terbiasa menyelesaikan permasalahan matematika yang berkaitan dengan berpikir kritis, 2) mahasiswa kurang kreatif dalam memilih atau mencari strategi yang tepat sesuai dengan permasalahan yang diberikan, 3) mahasiswa kurang teliti dalam menyelesaikan permasalahan matematika. Saran bagi penelitian ini adalah: 1) dosen memberikan bantuan kepada siswa yang 
mengalami kesulitan dalam menyelesaikan masalah, mahasiswa harus sering diberikan permasalahan yang mampu menumbuhkan berpikir kritis mahasiswa, mahasiswa harus terbiasa diberikan permaslahan-permasalahan tingkat tinggi.

\section{DAFTAR PUSTAKA}

Brillian Rosy \& Triesninda Pahlevi. (2015). Penerapan Problem Based Learning untuk Meningkatkan Kemampuan Berpikir Kritis dan Keterampilan Memecahkan Masalah. Prosiding Seminar Nasional, ( 9 Mei 2015).

Ennis, R. H. (1991). Goals for a Critical Thinking. Illinois Critical Thinking Project: University Illinois. Garofalo, J., \& Lester Jr, F. K. (1985). Metacognition, cognitive monitoring, and mathematical performance. Journal for research in mathematics education, 163-176.

Haryani, D. (2011). Pembelajaran matematika dengan pemecahan masalah untuk menumbuhkembangkan kemampuan berpikir kritis siswa. In Prosiding Seminar Nasional Penelitian, Pendidikan dan Penerapan MIPA, Fakultas MIPA, Universitas Negeri Yogyakarta (Vol. 14).

Istianah, E. (2013). Meningkatkan kemampuan berpikir kritis dan kreatif matematik dengan pendekatan model eliciting activities (MEAs) pada siswa SMA. Infinity Journal, 2(1), 43-54.

Ibrahim (2007). Pengembangan Kemampuan Berpikir Kritis dan Kreatif Siswa SMP dalam Matematika melalui Pendekatan Advokasi dengan Penyajian Masalah Open-Ended. Tesis Sekolah Pasca Sarjana UPI. Bandung: Tidak dipublikasikan

Komariah, K. (2011). Penerapan metode pembelajaran pemecahan masalah model polya untuk meningkatkan kemampuan memecahkan masalah bagi siswa kelas IX J di SMPN 3 Cimahi. In Prosiding Seminar Nasional Penelitian, Pendidikan dan Penerapan MIPA, Fakultas MIPA, Universitas Negeri Yogyakarta (Vol. 1).

Lubis, J. A. (2017). Pengaruh Penerapan Model Pembelajaran Pemecahan masalah Pada Kemampuan Berpikir Kritis Mahasiswa. Jurnal Pendidikan Biologi, 6(2), 291-295.

Maulana, M. (2017). Konsep dasar matematika dan pengembangan kemampuan berpikir kritis-kreatif. UPI Sumedang Press.

Palobo, M. (2015). Mengembangkan Kemampuan Berpikir Kreatif Melalui Pembelajaran ProblemPosing Dan Pemecahan masalah. In Seminar Nasional Matematika dan Pendidikan Matematika UNY. Yogyakarta: Universitas Negeri Yogyakarta.

Paul Eggen \& Don Kauchak. (2012). Strategi dan Model Pembelajaran (mengajarkan konten dan keterampilan berpikir). Indeks, Jakarta Barat.

Polya, G. 1973. How To Solve it: A New Aspect of Mathematical Method. New Jersey, USA: Pricenton University Press 
Analisis Kemampuan Koneksi Matematis Siswa SMK Pada Materi Fungsi Kelas XI, Arpin Chronika Saida Manalu, Asri Septiahani, Bunga Permaganti, Melisari, Yeti Jumiati, Wahyu Hidayat

Ristiasari, T., Priyono, B., \& Sukaesih, S. (2012). Model pembelajaran pemecahan masalah dengan mind mapping terhadap kemampuan berpikir kritis siswa. Journal of Biology Education, 1(3).

Sani, R. A. (2019). Pembelajaran Berbasis HOTS (Higher Order Thinking Skills). Tangerang: Tira Smart.

Undang-undang Permendikbud, No 23 Tahun 2016. Tentang Standar Penilaian Pendidikan.

Wiliawanto, W., Bernard, M., Akbar, P., \& Sugandi, A. I. (2019). Penerapan Strategi Pembelajaran Aktif Question Student Have Untuk Meningkatkan Kemampuan Berpikir Kritis Matematik Siswa SMK. Jurnal Cendekia: Jurnal Pendidikan Matematika, 3(1), 139-148. 